artigo original

\author{
Camila Guimarães \\ Leonardo R.L. Pereira \\ Néson I ucif Júnior \\ E vandro o óe C esarino \\ Carlos A.N . de AImei da \\ Dermeval de Carvalho \\ R egina H.C. Queiroz
}

\section{Tolerability and Effectiveness of Fluoxetine, Metformin and Sibutraminein Reducing A nthropometric and Metabolic Parameters in Obese Patients}

\begin{abstract}
The a im of this study is to assess the effects of sibutra mine (S) $15 \mathrm{mg} /$ day, fluoxetine (F) $60 \mathrm{mg} /$ day, and metfomin (M) 1,700 mg/day, as an adjunct therapy to a $1,500 \mathrm{kcal} / \mathrm{day}$ diet, in reducing anthropometric and metabolic parameters. $S(n=8), F(n=9)$, and $M(n=8)$ were compared to placebo $(n=10)$ in 35 obese patients in a 90-day trial. Side effects were also studied during the treatment. The data demonstrated that $F$ therapy resulted in a greater average reduction in $\mathrm{BMI}(11.0 \%)$, weight $(10.0 \%)$, abdominal c ircumference (11.0\%) and \%fatty-tissue (12.8). An elevation in HDL-cholesterol $(25.8 \%)$ and a reduction in average triglyceride levels $(28.3 \%)$ were also shown. Spresented a $7.91 \%$ reduction in the abdominal circumference and a 9.65 reduction in \%fatty-tissue was also found. M group presented reductions in $\mathrm{BMI}(4.03 \%)$, wa ist circ umference (6.92\%), HOMA (23.5\%) and blood pressure (6.08\% in systolic and $2.08 \%$ in diastolic). In general, the three drugs can be considered well tolerated. We concluded that $F$ and $S$ demonstrated a greater mean reduction in anthropometric and metabolic parameters when compared to $M$, howeverall of them are useful for that purpose, when the subjects' characteristics are considered. (Arq Bras Endoc rinol Metab 2006;50/6:1020-1025)
\end{abstract}

Keywords: Fluoxetine; Metformin; Obesity; Sibutra mine; Side effects

\section{RESUMO}

Tolerabilidade e Eficácia da Fuoxetina, Metfommina e Sibutramina na Redução de Parâmetros Antropométricos e Metabólicos em Pacientes Obesos.

O objetivo deste estudo foi ava liar o efeito da sibutramina (S) $15 \mathrm{mg} / \mathrm{dia}$, fluoxetina (F) $60 \mathrm{mg} / \mathrm{dia}$, e metformina (M) $1.700 \mathrm{mg} / \mathrm{dia}$, associadas a uma dieta de $1.500 \mathrm{kcal} / \mathrm{d}$ ia, na redução de parâmetros antropométricos e metabólicos. $S(n=8), F(n=9)$ e $M(n=8)$ foram comparadas ao placebo $(n=10)$ em 35 pacientes obesos durante 90 dias de tratamento. As reações adversas ta mbém foram avaliadas durante o tratamento. O grupo $\mathrm{F}$ demonstrou uma redução no $\operatorname{IMC}(11,0 \%)$, peso $(10,0 \%)$, circunferência abdominal (11,0\%) e \% de tecido adiposo $(12,8)$. Também fora m observados um a umento nos níveis de HDL-colesterol $(25,8 \%)$ e uma redução nos níveis de triglic érides (28,3\%), no grupo F. O grupo S apresentou uma redução de 7,91\% na circunferência abdominal e de 9,65 na \% de tecido a diposo. Já o grupo $M$ apresentou reduções no IMC $(4,03 \%)$, circunferência abdominal (6,92\%), HOMA (23,5\%) e pressão arterial $(6,08 \%$ na sistólica, $2,08 \%$ na diastólica). Os três fá ma cos analisados foram bem tolerados durante o tratamento. Concluímos que a $\mathrm{F}$ e a $\mathrm{S}$ demonstraram maior eficácia na redução dos parâmetros antropométricos e metabólicos dos pacientes obesos quando comparadas à $M$, entretanto todas podem ser prescritas para essa finalidade, desde que sejam consideradas a s caracteństic as ind ividua is dos pacientes. (Arq Bras Endocrinol Metab 2006;50/6:1020-1025)

Descritores: Fluoxetina; Metformina; Obesidade; Sibutramina; Reações adversas
R ecebi do em 04/ 11/ 05

R evisado em 29/03/06

A ceito em 16/06/ 06 
0 BESITY HAS BEEN DEFINED in different ways over time, such as "excessive body fat" or "weight $20 \%$ above the ideal value". H owever, the literature itself does not provide an accurate definition of what either "ideal" or "excess" is $(1,2)$.

O besity is a "chronic disease characterized by excessive fat accumulation to such an extent that will compromise the health of an individual", and is generally related to incorrect eating habits, a sedentary life style and a consumption of highly caloric food (3).

The World $\mathrm{H}$ ealth $\mathrm{O}$ rganization (WH O) classifies overweight and obesity by using body mass index (BMI). A BMI over $25 \mathrm{~kg} / \mathrm{m}^{2}$ is defined as overweight, and a BM I of over $30 \mathrm{~kg} / \mathrm{m}^{2}$ as obese (4).

$O$ verweight and obesity have become a world epidemic (5), which affects all ages and socioeconomic groups in both developed and developing countries (4). The International O besity Task Force (IOTF) estimates that about 1.7 billion individuals all over the world may be overweight or obese (6).

A recent study reported that $26 \%$ of Americans are considered obese and $35 \%$ are classified as overweight. This fact shows that during the last decades, the prevalence of obesity has increased dramatically all over the world (7).

In Brazil, according to the Brazilian Institute of Geography and Statistical (IBGE), $40.6 \%$ of the subjects with age over 20 years are overweight, and $11 \%$ of them are obese. In 2003, $41.1 \%$ and $8.9 \%$ of the adult men and $40 \%$ and $13.1 \%$ of the adult women were overweight and obese, respectively (8).

$O$ besity can be evaluated by anthropometric methods (9), especially BM I, considered a practical, fast and low cost method that can be used to estimate the total amount of body fat (10). H owever, a limitation of the BM I is that it does not differentiate between muscle and fatty tissue (11). N evertheless, it is a method extensively used in international studies, regarded as quite reliable when used together with the measurements of abdominal circumference and bioimpedance.

Laboratory methods such as blood count and the determination of urea, creatinine, uric acid, glycemia, total cholesterol, cholesterol fractions and triglycerides are also used for the evaluation of comorbidities associated with obesity (9).

Some patients have proved to be completely impotent and dissatisfied with the conventional treatment based on dietary reeducation and physical activity. In addition to that, pharmacological treatment, after being ignored for many years, is currently attracting more and more interest and is believed to become the best modality available for the obesity treatment
(12). That treatment, however, is only recommended as a part of an overall weight reduction program, together with some changes in lifestyle $(13,14)$. Pharmacotherapy is also stimulated by the progresses in the understanding of the biological basis of body weight regulation, and has proved to be safe and effective in maintaining weight over a long period of time (15), mainly when a new generation of anti-obesity drugs, such as sibutramine and orlistat, among others, are prescribed.

Sibutramine inhibits the reuptake of serotonin and norepinephrine and this sympathomimetic drug was approved by the FDA for the chronic use in obesity treatment and was brought to the market in 1998 (16).

Fluoxetine, a drug approved for use in the treatment of depression, acts specifically by blocking reuptake of serotonin (5-H T), a neurotransmitter which is believed to reduce food intake (17), at nerve endings (18). It is also postulated that fluoxetine could either generate a reduction in body weight gain by inhibiting neuropeptide $Y$ (NPY) action in the paraventricular nucleus of the hypothalamus, where N PY presents its hyperphagic effects $(19,20)$.

$M$ etformin is an oral antidiabetic drug used in the treatment of D iabetes M ellitus Type 2, which acts decreasing the glucose production by the liver and increasing the peripheral glucose uptake through the elevation of the number of insulin receptors (21). The mechanism by which metformin could reduce food intake is unknown but it is postulated that the reduction in the insulin resistance promotes some changes in energy balance that could reduce the daily caloric necessity of the individual and, as a result, a minor consumption of food (22).

A survey of the literature has shown that there is a need for new anti-obesity drugs, posing a challenge to researchers to find more effective and safer medicines for the treatment of this disease.

In this context, the main objective of the present study was to assess the tolerability and effectiveness of fluoxetine, sibutramine and metformin in reducing anthropometric and metabolic parameters in obese patients, and to compare them to placebo.

\section{SUBJ ECTAND METHODS}

This study was randomized and single blind, and was conducted on 35 obese patients aged 18 to 51 years old, 31 women and 4 men divided into four groups. Before the beginning of the study, all patients were given treatment with dietary reeducation for 6 
months, but it was unsuccessful in reducing their body weight. All patients selected for the study had a BM I of more than $30 \mathrm{~kg} / \mathrm{m}^{2}$, inasmuch as pharmacological treatment is recommended only for patients with a BMI above $30 \mathrm{~kg} / \mathrm{m}^{2}$ or above $27 \mathrm{~kg} / \mathrm{m}^{2}$ when associated with co-morbidities such as dyslipidemia, hypertension, diabetes, osteoarthritis and sleep apnea (23).

Alcoholic patients, diabetic patients, pregnant and nursing women, as well as patients with acquired immunodeficiency and those with viral liver infections were all excluded from the study. The study protocol was approved by the Research Ethics Committee of the $U$ niversity of Ribeirão Preto. The volunteers were included in the study after receiving detailed information about it and signing a free and informed consent form.

Before the study, each patient was submitted to anthropometric, haemodynamic and metabolic evaluations (weight, height, BM I, abdominal circumference, blood pressure, \%atty-tissue, glucose, urea, creatinine, uric acid, total cholesterol, LDL-cholesterol, HDLcholesterol, insulin, HOM A, urine-I, AST, ALT, and Gama-GT). All selected patients received a plan of dietary reeducation containing, on average, 1,500 calories per day.

After being considered eligible for the study, the patient was assigned to a group receiving sibutramine (15 mg/ day Reductil ${ }^{\circledR}$, lot $\left.901308 \mathrm{~F} 01\right)$, metformin ( $1700 \mathrm{mg} /$ day Glifage ${ }^{\circledR}$, lot 1021133), fluoxetine ( $60 \mathrm{mg} /$ day $D$ aforin ${ }^{\circledR}$, lot $04 \mathrm{G} 089$ ) or placebo ( 3 tablets/ day). The treatment started and the patient was monitored by interviews held on the following days: zero, 7, 14, 21, 28, 35, 42, 49, 56, 63, 70, 77, 84, and 90. Anthropometric, haemodynamic and metabolic evaluations were performed on days zero, 42 and 90.

Weight $(\mathrm{kg})$ and height $(\mathrm{m})$ were measured with a Filizola ${ }^{\circledR}$ anthropometric scale. BMI was obtained by the ratio of weight $(\mathrm{kg})$ to height $(\mathrm{m})$ squared (9). The patients were always weighed while wearing only a hospital gown.

According to WHO recommendations, the abdominal circumference is measured half way between the last rib and the iliac crest in the position of inspiration using a measuring tape $(9,24,25)$.

Arterial pressure was measured with an 0 xigel ${ }^{\circledR}$ sphygmomanometer, always at the same time of the day. The percentage of fatty tissue was assessed by bioelectric impedance using a model 101-A RJL Prizum apparatus with TBW electrodes (4).

The tests were performed using the GraphPad Instat ${ }^{\circledR}$ and Statgraphics ${ }^{\circledR}$ software for analysis of the means (AN OVA), Student t-test and multiple comparisons between groups (T ukey-Kramer test), with the level of significance set at $p<0.05$.

\section{RESULTS}

The data demonstrated that fluoxetine therapy resulted in a greater average reduction in BM I $(11.0 \%)$, weight (10.0\%), abdominal circumference (11.0\%) and \%atty tissue (12.8) (table 1). An elevation in HDLcholesterol (25.8\%) and a reduction in average triglyceride levels (28.3\%) were also shown, when compared with the other three drugs (table 2). Sibutramine presented a $7.91 \%$ reduction of the abdominal circumference and a $9.65 \%$ reduction in \%atty-tissue (table 1 ). $M$ etformin presented reductions in BMI $(4.03 \%)$, waist circumference $(6.92 \%), \mathrm{HOMA}(23.5 \%)$ and blood pressure $(6.08 \%$ in systolic and $2.08 \%$ in diastolic) (tables 1 and 2). The placebo group presented a significant increase $(p>0.05)$ in insulin levels of $95.1 \%$ (table 2).

In the sibutramine group, the side effects most often reported by the patients were mouth dryness (79.2\%), constipation (41.7\%), sudoresis (45.8\%), insomnia (20.8\%) and headache (16.7\%). In the metformin group, the main side effects reported were diarrhea $(45.8 \%)$, mouth dryness $(37.5 \%)$, sudoresis $(29.2 \%)$, vertigo $(29.2 \%)$, nausea $(25.0 \%)$ and altered palate (20.8\%).

In the fluoxetine group, the adverse reactions more commonly reported by the patients were anorexia (92.6\%), insomnia (29.6\%), sleepiness (29.6\%), nausea (14.8\%) and sexual dysfunction (11.1\%), while in the placebo group, the adverse reactions more commonly reported were anorexia (13.3\%), thirst (6.7\%) and diarrhea (6.7\%).

\section{DISCUSSION}

Sibutramine was prescribed at a dose of $15 \mathrm{mg} /$ day and was administered daily at about 9:00 a.m., a time considered safe to prevent episodes of insomnia. The usual initial dose of sibutramine is $10 \mathrm{mg} /$ day; however, we opted for $15 \mathrm{mg} /$ day because, according to Gokcel et al. (9), patients who receive $10 \mathrm{mg} /$ day report hunger during the night. The metformin dose prescribed to the patients was $1,700 \mathrm{mg} /$ day, divided into two administrations of $850 \mathrm{mg}$, the first a few minutes after lunch and the second after dinner. This dose has been reported to be safe and effective in pro- 
Table 1. Anthropometric and hemodynamic parameters (average \pm SD) of obese patients before and after the phamacologic al trea tment.

\begin{tabular}{|c|c|c|c|c|c|c|c|c|c|c|c|c|}
\hline \multirow[b]{2}{*}{ Parameters } & \multicolumn{3}{|c|}{ SIBUTRAMINE } & \multicolumn{3}{|c|}{ MEIFORMIN } & \multicolumn{3}{|c|}{ RUOXETINE } & \multicolumn{3}{|c|}{ PLACEBO } \\
\hline & BEFORE & AFIER & $\%$ & BEFORE & AFIER & $\%$ & BEFORE & AFIER & $\%$ & BEFORE & AFIER & $\%$ \\
\hline Age (years) & & 30.2 & & & 38.9 & & & 30.9 & & & 31.4 & \\
\hline Height (m) & & 1.63 & & & 1.61 & & & 1.60 & & & 1.56 & \\
\hline Weight (kg) & $\begin{array}{c}84.5 \\
( \pm 6.998)\end{array}$ & $\begin{array}{c}78.7 \\
( \pm 6.774)\end{array}$ & $-6.86^{n s}$ & $\begin{array}{c}95.5 \\
( \pm 14.14)\end{array}$ & $\begin{array}{c}91.9 \\
( \pm 13.44)\end{array}$ & $-3.77^{n s}$ & $\begin{array}{c}92.3 \\
( \pm 10.070)\end{array}$ & $\begin{array}{c}83.0 \\
( \pm 9.016)\end{array}$ & $-10.0^{\text {ns }}$ & $\begin{array}{c}78.7 \\
( \pm 9.975)\end{array}$ & $\begin{array}{c}77.7 \\
( \pm 10.657)\end{array}$ & $-1.30^{\text {ns }}$ \\
\hline BMI $\left(\mathrm{kg} / \mathrm{m}^{2}\right)$ & $\begin{array}{c}32.0 \\
( \pm 2.415)\end{array}$ & $\begin{array}{c}29.8 \\
( \pm 2.701)\end{array}$ & $-6.87^{n s}$ & $\begin{array}{c}37.2 \\
( \pm 5.821)\end{array}$ & $\begin{array}{c}35.7 \\
( \pm 5.556)\end{array}$ & $-4.03^{n s}$ & $\begin{array}{c}36.1 \\
( \pm 3.167)\end{array}$ & $\begin{array}{c}32.4 \\
( \pm 2.555)\end{array}$ & $-10.1^{*}$ & $\begin{array}{c}32.2 \\
( \pm 3.237)\end{array}$ & $\begin{array}{c}31.8 \\
( \pm 3.432)\end{array}$ & $-1.40^{\mathrm{ns}}$ \\
\hline $\begin{array}{l}\text { Abdominal } \\
\text { Circumference }\end{array}$ & $\begin{array}{c}103.7 \\
( \pm 4.472)\end{array}$ & $\begin{array}{c}95.5 \\
( \pm 4.552)\end{array}$ & $-7.91 *$ & $\begin{array}{c}117.1 \\
( \pm 14.30)\end{array}$ & $\begin{array}{c}109.0 \\
( \pm 11.08)\end{array}$ & $-6.92^{n s}$ & $\begin{array}{c}111.7 \\
( \pm 6.538)\end{array}$ & $\begin{array}{c}99.3 \\
( \pm 5.196)\end{array}$ & $-11.0^{*}$ & $\begin{array}{c}101.4 \\
( \pm 5.296)\end{array}$ & $\begin{array}{c}98.5 \\
( \pm 5.720)\end{array}$ & $-2.90^{\text {ns }}$ \\
\hline P.A. $(\mathrm{mm} / \mathrm{Hg})$ & $\begin{array}{c}118 / \\
75\end{array}$ & $\begin{array}{c}117 / \\
80\end{array}$ & $\begin{array}{l}-0.08^{n s} \\
+6.67 n s\end{array}$ & $\begin{array}{c}148 / \\
96\end{array}$ & $\begin{array}{c}139 / \\
94\end{array}$ & $\begin{array}{l}-6.08^{n s} \\
-2.08^{n s}\end{array}$ & $\begin{array}{c}145 / \\
104\end{array}$ & $\begin{array}{c}136 / \\
98\end{array}$ & $\begin{array}{l}-6.29^{n s} \\
-5.16^{n s}\end{array}$ & $\begin{array}{c}136 / \\
99\end{array}$ & $\begin{array}{c}130 / \\
91\end{array}$ & $\begin{array}{l}-4.94^{\text {ns }} \\
-8.59^{n s}\end{array}$ \\
\hline$\%$ Adipose tissue & $\begin{array}{c}34.2 \\
( \pm 8.049)\end{array}$ & $\begin{array}{c}30.9 \\
( \pm 8.758)\end{array}$ & $-9.65^{n s}$ & $\begin{array}{c}38.6 \\
( \pm 8.535)\end{array}$ & $\begin{array}{c}37.9 \\
( \pm 8.202)\end{array}$ & $-1.81^{\text {ns }}$ & $\begin{array}{c}36.4 \\
( \pm 6.135)\end{array}$ & $\begin{array}{c}31.7 \\
( \pm 2.302)\end{array}$ & $-12.8^{*}$ & $\begin{array}{c}34.0 \\
( \pm 4.818)\end{array}$ & $\begin{array}{c}34.1 \\
( \pm 7.397)\end{array}$ & $+0.20^{\mathrm{ns}}$ \\
\hline
\end{tabular}

ns: not signific ant, $p>0.05$; *: sta tistic ally signific ant, $p<0.05$.

Table 2. Some metabolic parameters (average \pm SD) of obese patients before and after the phamacological treatment.

\begin{tabular}{|c|c|c|c|c|c|c|c|c|c|c|c|c|}
\hline \multirow[b]{2}{*}{ Parameters } & \multicolumn{3}{|c|}{ SIBUIRAMINE } & \multicolumn{3}{|c|}{ MEIFORMIN } & \multicolumn{3}{|c|}{ RUOXEIINE } & \multicolumn{3}{|c|}{ PLACEBO } \\
\hline & BEFORE & AFIER & $\%$ & BEFORE & AFIER & $\%$ & BEFORE & AFIER & $\%$ & BEFORE & AFIER & $\%$ \\
\hline $\begin{array}{l}\mathrm{HDL}- \\
\text { cholesterol }\end{array}$ & $\begin{array}{c}57.0 \\
( \pm 22.53)\end{array}$ & $\begin{array}{c}50.0 \\
( \pm 19.47)\end{array}$ & $-12.3^{\text {ns }}$ & $\begin{array}{c}49.2 \\
( \pm 13.82)\end{array}$ & $\begin{array}{c}45.7 \\
( \pm 13.16)\end{array}$ & -7.1 & $\begin{array}{c}39.1 \\
( \pm 4.859)\end{array}$ & $\begin{array}{c}49.2 \\
( \pm 6.815)\end{array}$ & $+25.8^{*}$ & $\begin{array}{c}44.9 \\
( \pm 8.621)\end{array}$ & $\begin{array}{c}49.5 \\
( \pm 14.128)\end{array}$ & +10.2 \\
\hline Triglyc enides & $\begin{array}{c}89.2 \\
( \pm 19.90)\end{array}$ & $\begin{array}{c}100.2 \\
( \pm 47.71)\end{array}$ & $+12.3^{\text {ns }}$ & $\begin{array}{c}153.0 \\
( \pm 90.38)\end{array}$ & $\begin{array}{c}162.6 \\
( \pm 95.23)\end{array}$ & $+6.27^{n s}$ & $\begin{array}{c}137.9 \\
( \pm 55.871)\end{array}$ & $\begin{array}{c}98.9 \\
( \pm 37.866)\end{array}$ & $-28.3^{\text {ns }}$ & $\begin{array}{c}95.5 \\
( \pm 49.532)\end{array}$ & $\begin{array}{c}114.2 \\
( \pm 69.477)\end{array}$ & $+19.6^{\mathrm{ns}}$ \\
\hline Insulin & $\begin{array}{c}7.4 \\
( \pm 2.768)\end{array}$ & $\begin{array}{c}6.5 \\
( \pm 2.428)\end{array}$ & -12]$. & $\begin{array}{c}12.6 \\
( \pm 5.705)\end{array}$ & $\begin{array}{c}10.0 \\
( \pm 2.819)\end{array}$ & $-20.7^{n s}$ & $\begin{array}{c}10.2 \\
( \pm 5.664)\end{array}$ & $\begin{array}{c}11.9 \\
( \pm 9.694)\end{array}$ & $+17.1^{\text {ns }}$ & $\begin{array}{c}7.2 \\
( \pm 3.901)\end{array}$ & $\begin{array}{c}14.1 \\
( \pm 8.789)\end{array}$ & $+95.1^{*}$ \\
\hline HOMA & $\begin{array}{c}1.70 \\
( \pm 0.633)\end{array}$ & $\begin{array}{c}1.51 \\
( \pm 0.542)\end{array}$ & $-11.2^{\mathrm{ns}}$ & $\begin{array}{c}2.98 \\
( \pm 1.737)\end{array}$ & $\begin{array}{c}2.38 \\
( \pm 0.837)\end{array}$ & $-23.5^{n s}$ & $\begin{array}{c}2.04 \\
( \pm 1.072)\end{array}$ & $\begin{array}{c}2.436 \\
( \pm 2.039)\end{array}$ & $+19.1^{\text {ns }}$ & $\begin{array}{c}1.59 \\
( \pm 0.926)\end{array}$ & $\begin{array}{c}3.01 \\
( \pm 2.268)\end{array}$ & +89.3 \\
\hline Glic aemia & $\begin{array}{c}91.2 \\
( \pm 4.83)\end{array}$ & $\begin{array}{c}94.9 \\
( \pm 9.80)\end{array}$ & $+4.06^{\mathrm{ns}}$ & $\begin{array}{c}90.5 \\
( \pm 12.88)\end{array}$ & $\begin{array}{c}91.1 \\
( \pm 10.33)\end{array}$ & $+0.66^{\text {ns }}$ & $\begin{array}{c}83.1 \\
( \pm 10.5)\end{array}$ & $\begin{array}{c}82.8 \\
( \pm 6.6)\end{array}$ & $-0.4^{\mathrm{ns}}$ & $\begin{array}{c}89.0 \\
( \pm 12.8)\end{array}$ & $\begin{array}{c}83.4 \\
( \pm 7.9)\end{array}$ & $-6.3^{n s}$ \\
\hline
\end{tabular}

ns: not signific ant, $p>0.05 ;$ * statistic ally signific ant, $p<0.05$.

moting anorexic effects $(9,26,27)$. The fluoxetine dose prescribed was $60 \mathrm{mg} /$ day (three tablets of $20 \mathrm{mg}$ each) and was administered daily at about 9:00 a.m., after breakfast, to avoid side effects like nausea and vomiting (28). Placebo was administered in the same manner as fluoxetine.

The data of anthropometric and hemodynamic parameters are presented in table 1 , which shows that, before treatment, the average BMI of the patients assigned to sibutramine, metformin, fluoxetine and placebo groups was over of $30.0 \mathrm{~kg} / \mathrm{m}^{2}$. BM I is considered to be an attractive anthropometric measure because it requires minimal training of the person who obtains it and involves a low cost procedure. BMI has some limitations because it does not distinguish between adipose tissue and muscle mass. $\mathrm{H}$ owever, it is widely used in international studies and is quite reliable when used together with the measurement of abdominal circumference and other anthropometric methods (29-31). Table 1 shows that only fluoxetine treatment promoted a statistically significant $10.1 \%$ reduction in BMI $(p<0.05)$, while treatment with sibutramine, metformin and placebo also reduced BM I, but without statistical significance. The mean BM I reduction in the fluoxetine group permitted to change patient classification from moderately to slightly obese. Although the reduction of $B M I$ in the sibutramine group was not considered to be statistically significant, the mean BM I at the end of the study was $29.8 \mathrm{~kg} / \mathrm{m}^{2}$, which classifies the patients as overweight instead of slightly obese. In contrast, there were no modifications in the classification of the metformin and placebo groups. 
A survey of the literature has shown that the reduction of BMI promoted by fluoxetine was also described by several authors $(32,33)$, whereas Bray et al. (23) and Gokcel et al. (9) detected a reduction in BM I in patients treated with sibutramine.

Fluoxetine and sibutramine induced a nonsignificant reduction in body weight. $\mathrm{H}$ owever, in agreement with the literature, even discrete losses of 5 to $15 \%$ of the patient's initial body weight produce short-term benefits regarding several medical complications related to obesity, such as diabetes type 2, hypertension and dyslipidemias.

In the present study, the average abdominal circumference of the patients in fluoxetine, sibutramine, metformin, and placebo groups was of over $102 \mathrm{~cm}$ and $88 \mathrm{~cm}$, values considered safe for men and women, respectively (34). Abdominal obesity is an independent risk factor for morbidity and plays an important role in the development of hyperinsulinemia, insulin resistance, glucose intolerance, and dyslipidemia. Furthermore, some authors have demonstrated a correlation between abdominal circumference and cardiovascular disease. $\mathrm{O} n$ this basis, treatment of obesity aiming at a reduction in abdominal circumference could be of great value for selected patients (35).

At the end of the present study there was a significant reduction of $11.0 \%$ and $7.91 \%$ in the average abdominal circumference of patients treated with fluoxetine and sibutramine, respectively (table 1 ).

As shown in table 1, mean \%atty-tissue in all groups before the pharmacological treatment was above the recommended values (20-30\%). An important result shown in table 1 is that fluoxetine therapy induced a greater statistically significant $(p<0.05)$ reduction in \%atty-tissue (12.8\%).

Regarding blood pressure, we emphasize that sibutramine was the only drug studied to promote a change in this parameter, elevating diastolic blood pressure by about $6.7 \%$ This increase was not statistically significant but it may represent a risk for the patient when the drug is prescribed in an indiscriminate way.

An analysis of metabolic parameters showed that only metformin and sibutramine reduced the values of $\mathrm{HOMA}$ by $23.5 \%$ and $11.2 \%$, respectively, though these data were not statistically significant ( $p>$ $0.05)$. A reduction in this parameter was also observed by Gokcel et al. (9).

Conversely, the placebo group presented an elevation of $89.3 \%$ in the values of HOMA, caused by a statistically significant $(p>0.05)$ increase in plasma insulin levels (95.1\%). These findings suggest that physical activity and dietary reeducation, considered fundamental pillars for the obesity treatment, when allied to a rational pharmacotherapy, can produce more satisfactory results.

Fluoxetine, differently from the other drugs evaluated, caused a clinical and statistical significant increase in the plasma levels of $\mathrm{HDL}$, as shown in table 2 , and reduced the triglyceride levels (table 2). These findings are clinically relevant because dyslipidemia is a comorbidity intimately related to obesity.

In addition to the desirable anthropometric and cardiometabolic effects of the drugs, their side effects were also assessed. Also, a large number of patients in the sibutramine group reported sudoresis and the number was even higher in the intermediate and final phase of the study. This effect may probably be intimately related to the thermogenic effect of the drug.

In general, metformin proved to be more tolerable than sibutramine and fluoxetine. On one hand, metformin demonstrated a modest reduction of anthropometric parameters. However, sibutramine presented a greater reduction in some anthropometric parameters. This drug, however, demonstrated an elevation of blood pressure, a fact that demands a special care in the prescription of this drug for patients with high blood pressure.

Finally, fluoxetine also demonstrated a greater reduction in anthropometric parameters, as well as an increase of a metabolic parameter (HDL-cholesterol levels) and a reduction of another important metabolic parameter (triglycerides plasmatic levels).

In general terms, it was concluded that when prescribed in a rational way, taking the obese patient's physiopathologic conditions into consideration, and when associated to changes in diet and lifestyle, fluoxetine, sibutramine and metformin proved to be safe, welltolerated and effective drugs in reducing some anthropometric and metabolic parameters in obese patients.

\section{ACKNOWFDGEMENTS}

We are grateful to the Faculty of Pharmaceutical Sciences of Ribeirão Preto, U niversity of São Paulo, and CAPES for financial support.

\section{REFERENCES}

1. Bjomtorp P. Obesity. Lancet 1987;450:423-6.

2. Hirsch J. Obesity. Some heat but not enough light. Nature 1997;387:27-8. 
3. Associação Brasileira para o Estudo da Obesidade (ABESO). Available at: \htp:///www.abeso.org.br>.

4. World Health Orga nization (WHO). Ovenweightand obesity. 2003. Available at: \http:// www.who.int $>$ Accessed in: 31 may 2004.

5. Marks J B. Advances in obesity treatment: clinical highlights from the NAASO 2003 Annual Meeting. Clin Diab 2004;22:23-6.

6. James P. Chair of the London-based Intemational Obesity Task Force (IOTF). Monte Claro. March, 2003. Available at: 〈http:// www.iotf.org//media/iotfmar17.htm>

7. Hill J O, Billington CJ. It's time to start treating obesity. Am J Cardiol 2002;89:969-70.

8. Brazilian Institute of Geogra phy and Statistic al (IBGE). Family budgets research - POF 2002-2003. Weight excess can be verified in 38.8 millions Brazalian adults. 2004. Ava ila ble at: 〈htpp:// www.ibge.gov.br>. Accessed in: 5 jan. 2005.

9. Gokcel A, Gumurdulu $Y$, Karakose H, Melek Ertorer E, Tanaci N, BascilTutuncu N, et al. Evaluation of the safety and efficacy of sibutramine, orlistat and metformin in the treatment of obesity. Diabetes Obes Metab 2002;4:49-55.

10. Stunkard AJMD. Current views on obesity. Am J Med 1996;100(2):230-6.

11. Seidell JC, Kahn HS, Williamson DF, Lissner L, Valdez R. Report from a Centers for Disease Control and Prevention Workshop on use of adult anthropometry for public health and primary health care. Am J Clin Nutr 2001;73:123-6.

12. Atkinson RL. Use of drugs in the treatment of obesity. Annu Rev Nutr 1997;17:383-403.

13. Dastani HB, Brown CM, O'Donnel DC. Combating the obesity epidemic: community phamacists counseling on obesity management. Ann Pharmacotherapy 2004;38(11):1800-4.

14. loannides-Demos $\amalg$, Proietto J, Mcneil JJ. Phamacothera py for obesity. Drugs 2005;65(10):1391-418.

15. Ryan DH. Medicating the obese patient. Endocrinol Metab Clin North Am 1996;25(4):989-1004.

16. National Institutes of Health/National Heart Lung and Blood Institute, North Americ an Association for The Study of O besity (NHLBI/NAASO). Practical guide to the identification, evaluation, and treatment of overweight and obesity in adults. Bethesda, 2000.

17. Leibowitz SF, Weiss GF, Suh J. Medium hypothalamic nuclei mediate serotonin's inhibitory effect on feeding behaviour. Phamac Biochem Behav 1990;37:735-42.

18. Anelli M, Bizzi A, Caccia S, Cadegoni AM, Fracasso C, Farattini S. Anorectic activity of fluoxetine and norfluoxetine in mice, rats and guinea pigs. Phar Phamacol 1992; 44:1423-9.

19. Dryden S, Frankish HM, Wang Q, Pickavance L, Williams $G$. The serotonergic agent fluoxetine reduces neuropeptide $Y$ levels and neuropeptide $Y$ secretion in the hypothalamus of lean and obese rats. Neuroscience 1996;72:557-66.

20. Gutiérrez A, Saracibar G, Casis L, Echevaria E, Rodriguez VM, Maca rulla MT, et al. Effects of fluoxetine administration on neuropeptide $Y$ and orexins in obese Zucker rat hypothala mus. Obes Res 2002;10:532-40.
21. Bell PM, Hadden DR. Drug therapy: metformin. N Engl J Med 1996;334:574-9.

22. Rouru J, Huupponen R, Pesonen U, Koulu M. Sub-chronic treatment with metformin produces anorectic effect and reduces hyperinsulinemia in genetically obese Zucker rats. Life Sci 1992;50(23):1813-20.

23. Bray GA. A concise review on the thera peutic s of obesity. Nutrition 2000;16:953-60.

24. Macdonald IA. Obesity: are we any closer to identifying causes and effective treatments? TPS 2000;21:334-6.

25. Lean ME. How does sibutramine work? Int J Obes Relat Metab Disord 2001;25:8-11.

26. Rouru J, Pesonen U, Koulu M, Huupponen R, Santti E, Virtanen $\mathrm{K}$, et al. Anorectic effect of metformin in obese Zucker rats: lack of evidence for the involvement of neuropeptide Y. EurJ Phamacol 1995;273:99-106.

27. Pasquali R, Gambineri A, Bisc otti D, Vic ennati V, Gagliardi L, Colitta D, et al. Effect of long-term treatment with metformin added to hypocaloric diet on body composition, fat distribution, and androgen and insulin levels in abdominally obese women with and without the polycystic ovary syndrome. J Clin Endocrinol Metab 2000;85:2767-74.

28. Ferguson J M. SSRI antidepressant medic ations: adverse effects and tolerability. J Clin Psychiatry 2001;3:22-7.

29. Garrow J S, Webster J. Quetelet's index as a measure of fatness. IntJ Obes Relat Metab Disord 1985;9:147-53.

30. Ellis $\mathrm{KJ}$, Abrams AS, Wong WW. Monitoring childhood obesity: assessment of the weight/height ${ }^{2}$ index. Am J Epidemiol 1999;150:939-46.

31. Ellis KJ. Select body composition methods can be used in field studies. Phisiol Rev 2000;80:649-80.

32. Pijl H, Koppeschaar HP,

33. Willekens FL, Op de Kamp I, Veldhuis HD, Meinders AE. Effect of serotonin re-uptake inhibition by fluoxetine on body weight and spontaneous food choice in obesity. IntJ Obes 1991;15(3):237-42.

34. L Z, Maglione M, Tu W, Mojica W, Arterbum D, Shugarman $L R$, et al. Meta-analysis: phamacologic treatment of obesity. Ann Intem Med 2005;142(7):532-46.

35. National Cholesterol Education Program (NCEP) Expert Panel On Detection, Evaluation And Treatment of High Blood Cholesterol In Adults (Adult Treatment Panel III) (NCEP-ATP III). JAMA 2001;285:2486-97.

36. Rexrode KM, Carey VJ, Hennekens CH, Walters EE, Cold itz GA, Stampfer MJ, et al. Abdominal obesity and coronary heart disease in women. JAMA 1998;280:1843-8.

\section{Endereço para comespondência:}

Leonardo R.L. Pereira

Departamento de Ciências Farmacêuticas

Faculdade de Ciências Fa macêuticas de

Ribeirão Preto - USP

Av. do Café $s / \mathrm{n}$

14040-903 Ribeirão Preto, SP

E-mail: Ipereira @fc frp.usp.br 